\title{
Błędy w pomiarach wielkości fizycznych na przykładzie wybranych metod badań nieniszczących złączy spawanych
}

\author{
Errors in measurement of physical quantities based \\ on selected methods of nondestructive testing of welds
}

\section{Streszczenie}

W artykule przedstawiono zagadnienia związane $z$ tematyką błędów występujących w pomiarach różnych wielkości na przykładzie badań nieniszczących złączy spawanych. Opisano podstawowe rodzaje błędów oraz sposoby szacowania niepewności pomiarowych. Część teoretyczna została poparta przykładami opisu badań nieniszczących złączy spawanych, szczególnie badań magnetyczno-proszkowych.

\section{Abstract}

The paper presents issues related to the topic of errors in measurements of various sizes on the example of non-destructive testing of welds. Describes the basic types of errors, and ways of estimating uncertainty of measurement. The theoretical part was supported by the examples described based on the tests of welded joints of non-destructive testing and in particular magnetic-powder testing.

\section{Wstęp}

Pomiary wielkości fizycznych powinny być dokonywane $z$ określoną dokładnością. Wynika to $z$ niedoskonałości urządzeń pomiarowych oraz nieprecyzyjności ludzkich zmysłów. Podawanie samego wyniku pomiaru jest niewystarczające, opracowanie pomiarów powinno zawierać także miarę ich wiarygodności, czyli ocenę niepewności pomiaru. W celu przedstawienia wiarygodnych wyników powstała teoria niepewności pomiaru (zwana wymiennie rachunkiem niepewności pomiaru) [2].

\section{Pomiar i niepewność}

Pomiar jest to proces oddziaływania przyrządu pomiarowego $z$ badanym obiektem, zachodzący w czasie i przestrzeni, którego wynikiem jest uzyskanie informacji o właściwościach mierzonego obiektu. Pomiar to także zespół czynności wykonywanych w celu

Mgr inż. Karolina Poch, mgr inż. Piotr Wojtas - Politechnika Częstochowska. ustalenia miary określonej wielkości fizycznej lub umownej, jako iloczynu jednostki miary oraz liczby określającej wartość liczbową tej wielkości, tzn. porównywanie wartości danej wielkości z jednostką miary. Wynik pomiaru musi zawsze składać się z dwóch części: wartości liczbowej oraz jednostki.

Metoda pomiarowa to zastosowany podczas pomiaru sposób porównywania. Opracowano wiele metod pomiarowych różniących się między sobą sposobem postępowania oraz wyborem odpowiednich środków pomiarowych. Zawsze jednak do wykonania pomiaru, tj. określenia stosunku wartości mierzonej do wartości rzeczywistej, przyjętej za jednostkę miary, niezbędne jest określenie odpowiedniej jednostki miary oraz dobór odpowiedniego narzędzia pomiarowego [2].

Wyróżnia się następujące rodzaje pomiarów fizycznych: bezpośrednie, pośrednie, ciągłe i dyskretne.

Pomiary bezpośrednie są najprostszymi metodami, polegającymi na porównaniu danej wielkości z odpowiednią miarą wzorcową. Przykładami mogą być: pomiar wymiarów danego obiektu za pomocą linijki bądź suwmiarki, pomiar czasu trwania procesu lub zjawiska, pomiary wartości danej wielkości za pomocą odpowiedniego przyrządu pomiarowego. 
Dokonując pomiaru pośredniego, wartość badanej wielkości wyznacza się na podstawie pomiarów bezpośrednich innych wielkości fizycznych, które są powiązane $z$ nią znanym prawem fizycznym. Prostym przykładem jest wyznaczenie wartości przyspieszenia ziemskiego na podstawie okresu drgań wahadła matematycznego [1].

Okres drgań wahadła opisuje wzór:

$$
T=2 \pi \sqrt{l / g}
$$

gdzie: $T$ - okres drgań wahadła, $1 / \mathrm{s} ; /$ - długość nici wahadła, m; $g$-wartość przyspieszenia ziemskiego, $\mathrm{m} / \mathrm{s}^{2}$.

Po przekształceniu wzoru otrzymuje się zależność pozwalającą obliczyć wartość przyspieszenia ziemskiego:

$$
g=\frac{4 \pi^{2} l}{T^{2}}
$$

Zatem w celu obliczenia wartości przyspieszenia ziemskiego $g$ trzeba zmierzyć okres drgań wahadła $T$ oraz długości nici $l$.

W zależności od wyboru metody pomiarowej, wartości niektórych wielkości fizycznych mogą być wyznaczane metodą pomiarów pośrednich i bezpośrednich.

Pomiar ciągły umożliwia uzyskanie ciągłego zbioru wartości wielkości mierzonych. Przykładem jest pomiar prędkości jadącego pojazdu, kiedy w chwili przyspieszenia otrzymuje się odpowiednią chwilową prędkość.

Pomiar dyskretny dostarcza wyniki wartości mierzonych w sposób punktowy. Jest on prowadzony cyklicznie, niekoniecznie w sposób regularny. Przykładem jest kontrola poziomu oleju w samochodzie lub pomiar temperatury ciała. Pomiary dyskretne dokonywane są tylko w momencie zapotrzebowania na dany wynik mierzonej wartości [1].

Niepewność pomiarowa jest związana z wynikiem pomiaru i jest parametrem charakteryzującym rozrzut wyników, który można w uzasadniony sposób przypisać wartości mierzonej. Definicja wskazuje, że możliwe są różne miary niepewności. Do określenia niepewności pomiaru bezpośredniego wykorzystuje się dwie miary: podstawową jest niepewność standardowa $u(x)$, drugą miarą przydatną $w$ określonych sytuacjach jest niepewność graniczna $\Delta x[1]$.

W przypadku niepewności granicznej $\Delta x$ powinno się określić przedział:

$$
x_{0}-\Delta x<x_{i}<x_{0}+\Delta x
$$

w którym mieszczą się wszystkie otrzymane wyniki pomiaru wielkości $x_{i}$, co przedstawiono na rysunku 1.

Niepewność graniczna jest miarą deterministyczną, ponieważ wartość prawdziwa zawarta jest w przedziale $x_{0} \pm \Delta x$. Niepewność maksymalna jest stosowana w określonych sytuacjach, np. jako miara dokładności elektrycznych przyrządów pomiarowych.

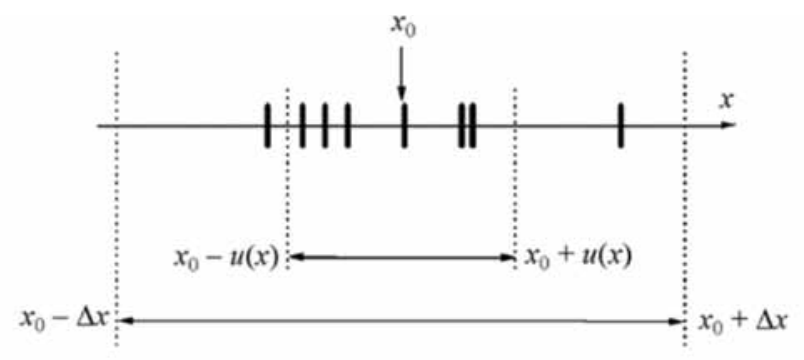

Rys. 1. Rozrzut wyników pomiaru [5]

Fig. 1. The dispersion of measurement results [5]

Miarą dokładności pomiaru najpowszechniej stosowaną i uznaną za podstawowa jest niepewność standardowa. Jej najkrótszą definicją jest: oszacowanie odchylenia standardowego. Niepewność standardowa u jest miarą średniego odchylenia wyników pomiarów od wartości rzeczywistej, zatem część wyników (ok. 1/3) znajdzie się poza przedziałem $\left(x_{0}-u(x), x_{0}+u(x)\right.$.

Niepewność $u$ ma wymiar taki jak wymiar wielkości mierzonej.

Określa również niepewność względną. Jest ona określana jako stosunek niepewności bezwzględnej do wartości mierzonej co określa wzór [1]:

$$
w(x)=\frac{u(x)}{x}
$$

gdzie: $w(x)$ - niepewność względna, $u(x)$ - niepewność standardowa, $x$ - wartość mierzona.

\section{Błędy pomiarowe}

Niezależnie od wybranej metody pomiarów, nie można wyznaczyć rzeczywistej wartości wielkości mierzonej. Wszystkie pomiary obarczone są niepewnościami, których nie można całkiem wyeliminować. Niepewność pomiaru jest nieodłączną cechą pomiaru i charakteryzuje rozrzut wyników pomiaru.

Błędy pomiarów dzieli się na: grube, przypadkowe i systematyczne [4].

Błędy grube powstają na skutek niestarannego podejścia obserwatora do odczytu mierzonej wartości i jej zapisu. W przypadku wykonywania serii pomiarów, błędy grube są łatwe do wykrycia i wyeliminowania.

Błędy przypadkowe nie wynikają z czynników systematycznych i powtarzalnych, co oznacza, że nie można z góry przewidzieć ich wartości w kolejnych pomiarach. Informację na temat skali ich występowania można uzyskać dopiero po wykonaniu serii pomiarów i wyliczeniu wybranej miary zróżnicowania rozkładu, np. odchylenia standardowego. Błędy te wskazują na przypadkową zmianę wyników. Nie można ich uniknąć, gdyż ich przyczyny są nieznane. Występowanie błędów przypadkowych można modelować za pomocą rozkładów statystycznych, np. rozkładu normalnego Gaussa (rys. 2). 


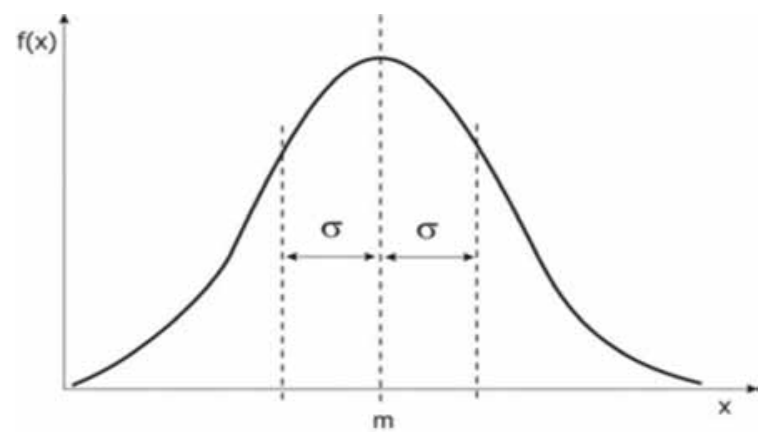

Rys. 2. Rozkład normalny Gaussa

Fig. 2. Gaussian normal distribution

Rozkład Gaussa jest rozkładem gęstości i prawdopodobieństwa $f(x)$ dla zmiennej losowej, która może przyjmować dowolne wartości rzeczywiste. Oznacza to, że prawdopodobieństwo znalezienia wartości zmiennej losowej w przedziale $\left(x_{1}, x_{2}\right)$, wyrażone jest wzorem:

$$
P\left(x_{1} \leq x \leq x_{2}\right)=\int_{x_{1}}^{x_{2}} f(x) d x
$$

gdzie

$$
f(x)=\frac{1}{\sigma \sqrt{2 \pi}} \exp \left(-\frac{(x-a)^{2}}{2 \sigma^{2}}\right)
$$

gdzie: $a$ - wartość średnia, $\sigma$-odchylenie standardowe

Jeżeli wartość $x_{1}$ zdąża do minus nieskończoności, a wartość $x_{2}$ do plus nieskończoności, to otrzymuje się warunek unormowania rozkładu, przedstawiający się następującą zależnością:

$$
\int_{-\infty}^{+\infty} f(x) d x=1
$$

co oznacza, że prawdopodobieństwo zdarzenia pewnego równe jest jedności [2]. Właśnie dlatego funkcja $f(x)$ zawiera czynnik $\sqrt{ } 2 \pi$, ponieważ:

$$
\int_{-\infty}^{\infty} e^{-x^{2 / 2}} d x=\sqrt{2 \pi}
$$

Ze wzoru (5) wynika, że rozkład Gaussa jest rozkładem symetrycznym względem a, kiedy funkcja gęstości prawdopodobieństwa przyjmuje wartość maksymalną. Wartość a jest wartością oczekiwaną dla rozkładu Gaussa. Wartość $\sigma$ jest odchyleniem standardowym.

Prawdopodobieństwo odpowiadające znalezieniu zmiennej losowej opisywanej rozkładem Gaussa w granicach całkowitej wartości odchylenia standardowego względem wartości oczekiwanej jest następujące:

$$
\begin{aligned}
& P(|x-a| \leq \sigma=68,3 \% \\
& P(|x-a| \leq 2 \sigma=95,4 \% \\
& P(|x-a| \leq 2 \sigma=99.8 \%
\end{aligned}
$$

Błędy systematyczne wynikają z zastosowanej metody pomiaru lub innych przyczyn, zmieniających wyniki pomiaru. Podstawowe przyczyny powstawania błędów systematycznych to: zmiany obiektu badanego

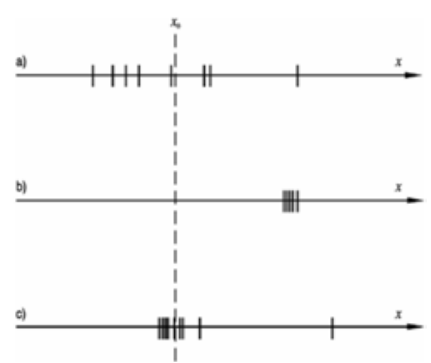

Rys. 3. Relacja wartości rzeczywistej $x_{0}$ i zbioru wyników pomiaru (zaznaczonych kreskami) na osi liczbowej: a) dla błędu przypadkowego, b) dla błędu systematycznego, c) dla kombinacji błędu przypadkowego i błędu grubego [5]

Fig. 3. The interplay of actual and set of measurement results (selected lines) on the number line: a) for random error, b) for systematic error, c) for a combination of random error and big error [5]

po dołączeniu do urządzenia lub układu pomiarowego, sposób wykonania przyrządów pomiarowych w zakresie skalowania, wzorcowania oraz montażu i wpływ czynników otoczenia na stanowisko pomiarowe. Przyczyny te mogą mieć wpływ na wystąpienie błędów systematycznych, w zależności od rodzaju parametru mierzonego oraz sposobu pomiaru. Ocena błędów systematycznych należy do osoby wykonującej pomiary, co pozwala na eliminację lub ich ograniczenie nawet w początkowej fazie pomiarów.

Błędy systematyczne powodują błędną ocenę wartości zmierzonej wielkości fizycznej, czyli w przypadku powtarzanego pomiaru otrzymany rozrzut wyników będzie taki jak dla błędu przypadkowego. Dlatego też przy wielokrotnym powtarzaniu pomiaru nie jest możliwe wykrycie błędu systematycznego. Wykrycie takiego błędu systematycznego jest możliwe przy zastosowaniu innej, niezależnej metody pomiaru.

Występowanie błędów systematycznych i przypadkowych charakteryzuje się zróżnicowanym charakterem rozrzutu oraz częstości występowania (rys. 3).

\section{Metody określania pomiarów pośrednich}

\section{Niepewność standardowa pomiarów bezpośrednich}

Wyniki pomiarów w serii różnią się losowo. Oznaczane są: $x_{1}, x_{2}, x_{3}, \ldots \ldots . x_{n}$, gdzie $n$ jest liczbą powtórzeń pomiaru w serii i powinna wynosić przynajmniej 10. Jej wartość rzeczywista nie jest znana, ale z serii pomiarów wartością najbardziej zbliżoną do rzeczywistej jest średnia arytmetyczna:

$$
x \approx \bar{x}=\frac{1}{n} \sum_{i=1}^{n} x_{i}
$$

Słuszność tego twierdzenia potwierdzają kolejne pomiary. Im ich jest więcej, tym bardziej precyzyjnie 
można określić błąd pomiarowy. W tym przypadku do określenia niepewności standardowej zaleca się stosowanie wzoru na odchylenie standardowe średniej:

$$
u(x)=\sqrt{s \frac{2}{x}}=\sqrt{\frac{\sum_{i=1}^{n}\left(x_{i}-\bar{X}\right)^{2}}{n(n-1)}}
$$

Jeśli wynikı pomıarow nıe wykazują rozrzutu, tj. wszystkie są równe, to niepewność pomiarową możemy oszacować na podstawie naukowego osądu obserwatora. Przykładem może być wykorzystanie informacji o niepewności maksymalnej $\Delta x$, określonej przez producenta urządzenia pomiarowego. W tym celu należy posłużyć się wzorem:

$$
u(x)=\frac{\Delta X}{\sqrt{3}}
$$

W przypadku prostych urządzeń pomiarowych, takich jak: linijka, śruba mikrometryczna czy termometr, za $\Delta x$ można przyjąć działkę elementarną przyrządu. W przyrządach elektronicznych niepewność maksymalna urządzenia podawana jest przez producenta w instrukcji obsługi i jest zwykle kilkakrotnie większa od działki elementarnej. Często wartość działki elementarnej zależy od wielkości mierzonej $(x)$ i zakresu pomiarowego $(z)$. Wówczas niepewność maksymalną określa się wzorem:

$$
\Delta x=c_{1} x+c_{2} z
$$

gdzie: $c_{1}, c_{2}$ - wartość działki elementarnej, $x$ - wielkość mierzona, $z$-zakres.

W przypadku wystąpienia dwóch wymienionym typów niepewności (np. rozrzutu wyników oraz niepewności wzorcowania) należy skorzystać z następującego wzoru:

$$
u(x)=\sqrt{s \frac{2}{x}}+\frac{(\Delta X)^{2}}{3}
$$

gdzie: $s$ - liczba pomiarów.

\section{Niepewność standardowa pomiarów pośrednich}

Rozważając występowanie niepewności standardowych pomiarów pośrednich, wielkość mierzoną oznacza się jako funkcję:

$$
y=f\left(x_{1}, x_{2}, \ldots, x_{k}\right)
$$

gdzie $x_{1}, x_{2}, \ldots, x_{\mathrm{k}}$ odpowiadają $k$ wielkości pomiarów fizycznych, mierzonych bezpośrednio.

Zakładamy, że znane są wyniki pomiarów tych wielkości oraz ich niepewności standardowe

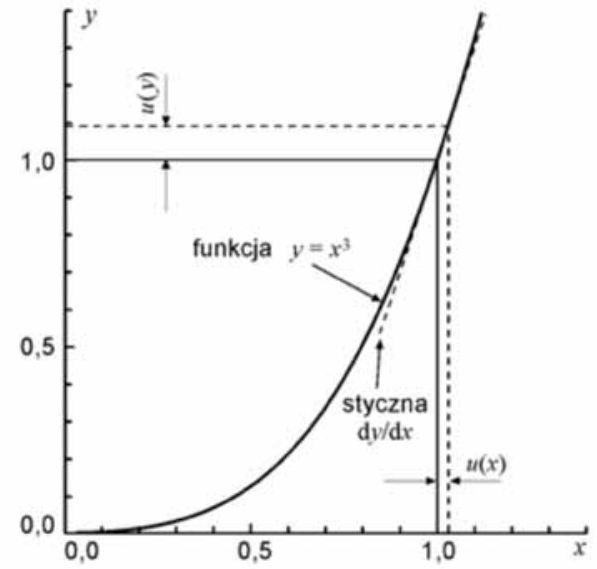

Rys. 4. Prezentacja propagacji niepewności

Fig. 4. Graphical representation of uncertainty propagation [1]

$u\left(x_{1}\right), u\left(x_{2}\right), u\left(x_{k}\right)$. Wówczas wynik pomiaru końcowego oblicza się na podstawie wzoru:

$$
y \approx \bar{y}=f\left(\overline{x_{1}} \overline{x_{2}}, \ldots, \bar{x}\right)
$$

W pomiarach pośrednich nieskorelowanych, tzn. gdy każdą z wielkości mierzy się niezależnie od pozostałych, niepewność złożoną wielkości y ocenia się wg prawa propagacji niepewności (rys. 4), które wyraża się wzorem:

$$
u(x)=\frac{d y}{d x} u(x)
$$

\section{Niepewność rozszerzona}

Niepewność standardowa całkowicie i jednoznacznie określa wartość wyniku, jednak do wnioskowania o zgodności wyniku pomiaru z innymi wynikami (np. z wartością tabelaryczną) oraz dla celów komercyjnych i do ustalania norm przemysłowych, zdrowia, bezpieczeństwa itp. Międzynarodowa Norma Oceny Niepewności Pomiarowych wprowadza pojęcie niepewności rozszerzonej oznaczanej symbolem $u$ (dla pomiarów bezpośrednich) lub $u_{c}$ (dla pomiarów pośrednich). Wartość niepewności rozszerzonej oblicza się ze wzoru:

lub

$$
u(y)=k u(x)
$$

$$
u_{c}=k u_{c}(x)
$$

Liczba k, tzw. współczynnik rozszerzenia, jest umownie przyjętą liczbą wybraną tak, aby w przedziale $x+u(x) \cdot x+u(x)$ znalazła się większość wyników pomiaru potrzebna dla danych zastosowań. Wartość współczynnika rozszerzenia mieści się najczęściej w przedziale $2 \div 3$. W większości zastosowań zaleca się przyjmowanie umownej wartości $k=2$. 


\section{Zapis wyników pomiaru z uwzględnieniem błędów pomiarowych}

Otrzymane wyniki mierzonej wielkości zapisuje się łącznie z niepewnością oraz jednostką, w jakiej wyrażana jest mierzona wartość. Niepewność podawana jest z dokładnością do dwóch cyfr znaczących, a liczbę cyfr znaczących wyniku dobieramy tak, aby ostatnia cyfra wyniku i niepewności należały do tego samego rzędu. Dla niepewności standardowych zalecany jest zapis z użyciem nawiasów, zaś dla niepewności rozszerzonej stosowany jest zapis z użyciem symbolu \pm [4].

$$
\mathrm{x}_{R}=\mathrm{x}_{M} \pm \Delta x
$$

gdzie: $x_{r}$ - wartość rzeczywista wielkości mierzonej, $x_{M}$ - wartość uzyskana w wyniku pomiaru, $\Delta x-$ niepewność lub błąd pomiaru.

Z podanego zapisu odczytuje się, że najlepszym przybliżeniem wartości mierzonej jest liczba $x_{m}$, której należy szukać w przedziale $\left(x_{m}-\Delta x\right)$ i $\left(x_{m}+\Delta x\right)$.

Przy zapisywaniu wyników pomiaru należy pamiętać, że:

- błąd pomiaru $\Delta x$ jest wielkością oszacowaną. Nie ma potrzeby podawania wszystkich cyfr otrzymanych w wyniku obliczeń. Obliczone wartości $x_{m}$ i $\Delta x$ podaje się zaokrąglone, czyli przybliżone;

- cyframi znaczącymi danej liczby różnej od zera nazywa się wszystkie jej cyfry z wyjątkiem występujących na początku zer. Do cyfr znaczących zalicza się również zera końcowe, jeśli są one wynikiem obliczeń, a nie zaokrągleń. Oznacza to, że pierwsza liczba znacząca musi być różna od zera, natomiast druga, trzecia i dalsze mogą być zerami;

- są cyfry pewne. Jeśli błąd spowodowany przybliżeniem liczby dziesiętnej jest mniejszy od jedności na ostatnim miejscu dziesiętnym, mówi się, że wszystkie jej cyfry są pewne. Przybliżenie dziesiętne podaje się wtedy z zachowaniem tylko cyfr pewnych, np. $125 \times 10^{3}$ lub $1,2^{5} \times 10^{5}$;

- przy zaokrąglaniu wyniku pomiaru stosowane są powszechnie przyjęte zasady zaokrągleń, tzn. liczbę kończącą się cyframi $0 \div 4$ zaokrągla się $w$ dół, a $5 \div 9$ w górę lub liczby $0 \div 4$ zaokrągla się $w$ dół, $6 \div 9$ w górę, cyfrę $5 \mathrm{w}$ dół, jeśli poprzedza ją cyfra parzysta, zaś w górę, jeśli poprzedza ją liczba nieparzysta. Można stosować dowolną z tych zasad, ale w jednym opracowaniu wyników pomiarów należy konsekwentnie stosować tylko jedną z nich;

- oszacowane błędy zaokrągla się w górę, ponieważ w żadnym przypadku nie wolno zmniejszać błędów;

- obliczenia wykonuje się zawsze z większą liczbą cyfr, niż podawany jest wynik. Zaokrągleń dokonuje się dopiero po zakończeniu obliczeń;

- błędy pomiarów zaokrąglane są do pierwszej cyfry znaczącej.
Ostatnia cyfra znacząca w każdym wyniku pomiaru powinna stać na tym samym miejscu dziesiętnym, co błąd pomiaru, np. nie powinno się podawać wyniku w postaci $u=(9,82 \pm 0,02389) \mathrm{V}$.

Trudno sobie bowiem wyobrazić, aby niepewność pomiarowa mogła być znana z dokładnością czterech cyfr znaczących.

Przy bardzo dokładnych pomiarach można czasem podawać wynik $z$ dwiema cyframi znaczącymi po przecinku, czyli w podanym przykładzie $\Delta u=0,02 \mathrm{~V}$ zatem:

$$
u=(9,82 \pm 0,02) \mathrm{V}
$$

Od podanej reguły jest wyjątek - jeśli pierwszą cyfrą znaczącą niepewności $\Delta x$ jest 1 (lub 2), to lepiej zachować dwie cyfry znaczące niepewności, np. $\Delta x=0,14$, gdyż zaokrąglenie do $\Delta x=0,1$ prowadzi do $40 \%$ zmniejszenia niepewności [5].

\section{Przykłady występowania błędów pomiarowych w procesach badawczych i technologicznych}

Występowanie błędów pomiarowych jest bardzo częstym zjawiskiem podczas pomiarów parametrów technologicznych odnoszących się do ściśle określonego procesu badawczego. Na szczególną uwagę zasługują pomiary w procesach spawalniczych oraz kontroli jakości złączy spawanych. Każdy parametr technologiczny odgrywa ważną rolę i ma wpływ na przeznaczenie wykonanej konstrukcji czy też urządzenia.

Biorąc pod uwagę procesy spawalnicze, można zauważyć, że prawdopodobieństwem wystąpienia błędów pomiarowych są obarczone pomiary natężenia prądu spawania, napięcia biegu jałowego, pomiary długości, szerokości oraz wysokości grani i lica spoiny, prędkości podawania drutu elektrodowego, prędkości spawania, napięcia łuku spawalniczego, energii liniowej łuku.

W odniesieniu do tych wielkości występują zarówno błędy grube, przypadkowe, jak i systematyczne, w zależności od sposobu prowadzenia pomiaru.

W badaniach złączy spawanych przykładem mogą być błędy zaobserwowane przez autorów podczas badań magnetyczno-proszkowych oraz ultradźwiękowych, gdzie zauważono błędy pomiarów natężenia pola magnetycznego, natężenia światła UV (bądź dziennego) i natężenia pola szczątkowego $[6,7]$.

\section{Błąd pomiaru natężenia pola magnetycznego}

Do pierwszej serii pomiarów został użyty miernik MP-100; wówczas wyniki pomiarów wskazywały wartości w zakresie 2,2 $\div 2,6 \mathrm{kA} / \mathrm{m}$. Drugą serię pomiarową wykonano miernikiem MP-U. Wtedy wyniki pomiarów 
Tablica I. Wyniki pomiarów natężenia pola magnetycznego Table I. Results of measurements of magnetic fields

\begin{tabular}{|c|c|c|c|}
\hline Typ miernika & Pomiar 1 & Pomiar 2 & Pomiar 3 \\
\hline $\mathrm{MP}-100$ & $2,54 \mathrm{kA} / \mathrm{m}$ & $2,6 \mathrm{kA} / \mathrm{m}$ & $2,57 \mathrm{kA} / \mathrm{m}$ \\
\hline $\mathrm{MP}-\mathrm{U}$ & $5,2 \mathrm{kA} / \mathrm{m}$ & $5,43 \mathrm{kA} / \mathrm{m}$ & $5,39 \mathrm{kA} / \mathrm{m}$ \\
\hline
\end{tabular}

mieściły się w zakresie $5,5 \div 6,5 \mathrm{kA} / \mathrm{m}$. Wartości pomiarów przedstawiono $\mathrm{w}$ tablicy $\mathrm{I}$. Zestawienie tych wyników wskazuje na duży rozrzut pomiędzy nimi, co oznacza, że któreś z urządzeń działa niepoprawnie. $Z$ dokumentacji dotyczącej wzorcowania i kalibrowania tych dwóch urządzeń wynika, że wzorcowanie pierwszego $z$ nich miało miejsce w 2010 r., natomiast drugiego w 2008 r. Wskazuje to na możliwość utraty poprawności wykonywanych pomiarów przez drugie urządzenie. Jednocześnie wyniki pomiarów pierwszym urządzeniem są bardziej wiarygodne, gdyż wartości odpowiadają wielkościom otrzymanych wskazań na określonych głębokościach. Jest to przykład sytuacji, kiedy przyczyną wystąpienia błędów pomiarowych jest zastosowanie dwóch różnych urządzeń lub brak aktualnej kalibracji i wzorcowania. Odnosi się to do wszystkich rodzajów wykonywanych pomiarów, nie tylko pomiaru natężenia pola magnetycznego.

Jest to przykład błędu systematycznego uwarunkowanego zmianą wyników pomiaru, wynikającą z zastosowania dwóch mierników wzorcowanych w dwóch różnych terminach. Otrzymane wyniki są jednostronnie zawyżane.

\section{Błąd pomiaru długości}

Podczas badań doczołowego złącza spawanego wykonywane były pomiary długości wskazania oraz analiza wyników. Każdy pomiar wykonywała inna osoba. Odchylenia nie były duże, jednak jednoznacznie wskazywały, że dla każdej osoby wartość długości wskazania była inna, co wynika z subiektywnej interpretacji intensywności wskazania, np. dla jednej osoby wskazanie może być intensywne na długości $60 \mathrm{~mm}$, a dla drugiej na długości $65 \mathrm{~mm}$. Uwarunkowane jest to predyspozycjami operatora.

Kolejnym przypadkiem błędu pomiaru długości jest nieprecyzyjność dokonywania pomiaru. W tablicy II przedstawion, wyniki pomiarów długości wskazań liniowych dokonane w dwóch seriach pomiarowych za pomocą suwmiarki. Uzyskane wyniki można zapisać jako $60 \pm 0,2 \mathrm{~mm}$, gdzie 0,2 jest błędem wynikającym z błędu odczytu pomiarowego.

\section{Błąd pomiaru grubości}

Podczas badań ultradźwiękowych złączy spawanych za pomocą wyskalowanego defektoskopu ultradźwiękowego USM 25 dla głowicy MWB 70-4, wykonywanych na dużej liczbie próbek o takich samych właściwościach materiałowych oraz wizualnie
Tablica II. Wyniki pomiarów długości wskazań liniowych (mm) Table II. Results of the linear length measurements indicated ( $\mathrm{mm}$ )

\begin{tabular}{|c|c|c|c|}
\hline & Pomiar 1 & Pomiar 2 & Pomiar 3 \\
\hline Seria 1 & 60,2 & 60,0 & 59,8 \\
\hline Seria 2 & 60,0 & 59,9 & 60,1 \\
\hline
\end{tabular}

podobnych do siebie, może wystąpić błąd wynikający z niewielkiej różnicy grubości badanych złączy.

Badanie wykonano na dwudziestu próbkach blach ze złączem doczołowym, oczyszczonych strumieniowo-ściernie. Do badania grubości użyto suwmiarki. Na podstawie zmierzonej grubości ośmiu próbek, która wyniosła $14 \mathrm{~mm}$, błędnie przyjęto założenie, że grubość pozostałych dwunastu elementów jest taka sama. W rzeczywistości zmierzona grubość osiemnastu próbek wynosi $14 \mathrm{~mm}$, a pozostałych dwóch $16 \mathrm{~mm}$. Zaniechanie pomiaru grubości dla całej partii próbek przyczyniło się do opisanych poniżej błędów. Przeprowadzając badanie za pomocą poprawnie wyskalowanego defektoskopu ultradźwiękowego dla ww. głowicy i grubości $14 \mathrm{~mm}$, można popełnić błąd w przypadku dwóch próbek, których grubość wynosi $16 \mathrm{~mm}$. Błędy te mogą dotyczyć: lokalizacji niezgodności oraz doboru wielkości płaskodennego reflektora tarczowego, którego wielkość ma wpływ na czułość badania. Na rysunku 5 przedstawiono wpływ zmian grubości badanego elementu na głębokość zalegania niezgodności.

Rysunek 5 przedstawia przykład wystąpienia przyklejenia brzegowego w pobliżu przetopu. Na rysunku 5a zilustrowano przebieg wiązki ultradźwiękowej dla grubości $14 \mathrm{~mm}$, który wskazuje prawidłową lokalizację niezgodności. Natomiast w przypadku próbki o grubości $16 \mathrm{~mm}$, której rzut przedstawiono na rysunku $5 b$, występuje błąd lokalizacji niezgodności. Ponieważ cyfrowy defektoskop ultradźwiękowy do obliczeń wykorzystuje niepoprawnie wprowadzoną grubość próbki $(14 \mathrm{~mm})$, zakłamanie występuje przy przeliczeniu głębokości zalegania niezgodności. Przyczyną niepoprawnie wprowadzonej grubości jest zła lokalizacja i nieodpowiednia wielkość niezgodności. Linią ciągłą czerwoną zilustrowano wykrycie niezgodności

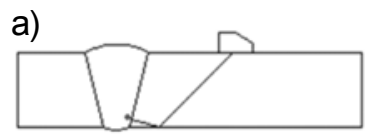

b)

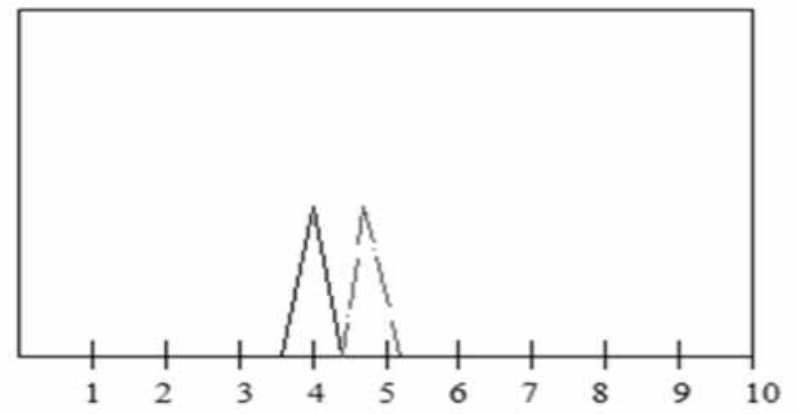

Rys. 5. Przebieg fali ultradźwiękowej w próbce oraz wskazanie na ekranie defektoskopu

Fig. 5. Ultrasonic waveform in the sample and indication on the screen flaw 


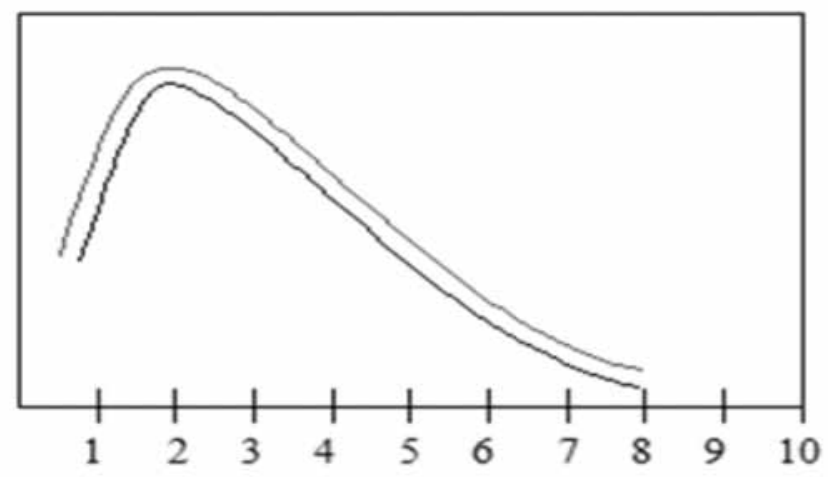

Rys. 6. Zmiana położenia linii odniesienia wskutek podwyższenia wzmocnienia o $3 \mathrm{~dB}$

Fig. 6. Repositioning if the reference line due to an increase of $3 \mathrm{~dB}$ to strengthen

z nieprawidłowo wprowadzoną grubością materiału, a linia przerywana obrazuje przekłamanie lokalizacji niezgodności.

Rozpatrując nieprawidłowe wprowadzenie grubości materiału dla dwóch badanych próbek, powinno zmienić się również średnicę reflektora płaskodennego w metodzie OWR. Dla próbki o grubości $14 \mathrm{~mm}$ średnica reflektora wynosi $1 \mathrm{~mm}$, a dla $16 \mathrm{~mm}$ powinna być zwiększona do $1,5 \mathrm{~mm}$. Różnica średnic dla tego przypadku to $0,5 \mathrm{~mm}$, co przekłada się na zmianę wzmocnienia o $3 \mathrm{~dB}$ (rys. 6).

$\mathrm{Na}$ rysunku 6 przedstawiono zmianę; linii odniesienia wskutek podwyższenia wzmocnienia, linia czarna charakteryzuje krzywą OWR dla poprawnie wyskalowanego defektoskopu dla grubości $14 \mathrm{~mm}$, natomiast linia jaśniejsza jest krzywą OWR po podwyższeniu wzmocnienia o $3 \mathrm{~dB}$. Jak widać, dla dwóch próbek o grubości $16 \mathrm{~mm}$ ocena wskazania dokonywana jest w ostrzejszy sposób niż zakładają to normy PN-EN 1712 i PN-EN 1714.

Kolejny przykład błędu systematycznego związany ze zmianą grubości badanego materiału został przedstawiony na podstawie pomiaru grubości

\section{Podsumowanie}

Korzystając z doświadczenia nabytego podczas badań, należy zauważyć że wystąpienie błędów zależy od poprawnej kalibracji i wzorcowania przyrządu pomiarowego oraz umiejętności osoby wykonującej pomiar. Niedoskonałość zmysłów oraz zawodność przyrządów pomiarowych istotnie wpływa na otrzymane wyniki pomiaru, a co za tym idzie, na efektywność badań czy też procesów technologicznych.

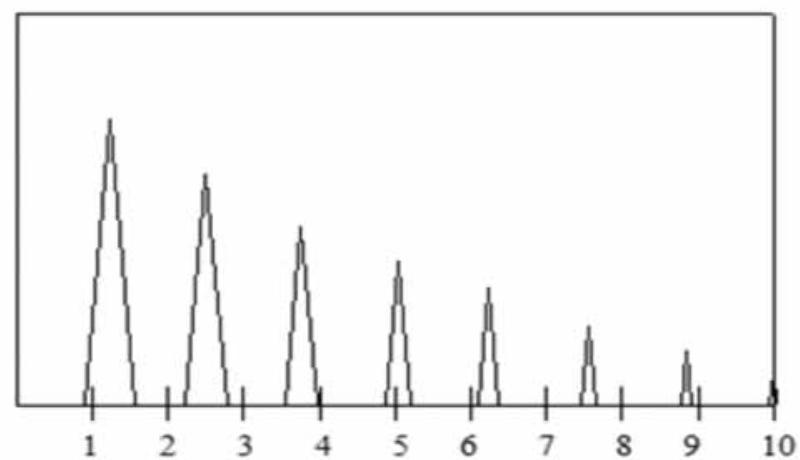

Rys. 7. Ekran defektoskopu po kalibracji

Fig. 7. Screen view after calibration

defektoskopem ultradźwiękowym. Do pomiaru użyto cyfrowego defektoskopu ultradźwiękowego USM 25 oraz głowicy SEB 4, przyrząd wyskalowano na grubości wzorca W2, tj. 12,5 mm. Na rysunku 7 przedstawiono widok ekranu defektoskopu po kalibracji. Pierwsze echo dna znajduje się na 1,25 działki ekranu, co odpowiada grubości $12,5 \mathrm{~mm}$, kolejne echa oddalone są od siebie o 1,25 działki.

Następnie wykonano pomiary grubości pięciu próbek, grubość czterech z nich była zbliżona do grubości wzorca W2 i wynosiła: 10,5; 16,3; 20,9 oraz $25 \mathrm{~mm}$. Przełożyło się to na właściwy pomiar grubości dokonanej defektoskopem, co potwierdził powtórny pomiar suwmiarką. Piąta próbka znacznie odbiegała grubością od pozostałych. Pomiar dokonany za pomocą defektoskopu wskazał $69,7 \mathrm{~mm}$, natomiast rzeczywista grubość zmierzona suwmiarką wynosiła $70,1 \mathrm{~mm}$. Rozbieżność $0,4 \mathrm{~mm}$ spowodowana jest tym, że grubość wzorca użytego do kalibracji jest niemal sześciokrotnie mniejsza od badanej grubości, czego przyczyną był niewłaściwy pomiar grubości. Należało zwiększyć zakres obserwacji oraz dokonać kalibracji na innym wzorcu, np. W1 (użyć wymiaru 100 mm).

\section{Literatura}

[1] Dudkiewicz J., Kusz B.: I laboratorium z fizyki. Część 2. Skrypt Politechniki Gdańskiej, Gdańsk 2002.

[2] Kilias J., Kostrzyński T., Wojciechowski S.: Podstawy fizyki dla studentów informatyki. WAT, Warszawa 2002.

[3] Dryński T.: Ćwiczenia laboratoryjne z fizyki. PWN, Warszawa 1963.

[4] Wyrażanie niepewności pomiaru: Przewodnik, Główny Urząd Miar, Warszawa 1999.

[5] Zięba A.: Pracownia fizyczna wydziału fizyki i techniki jądrowej AGH. Część 1. Wydawnictwo AGH, Kraków 2002.

[6] Krawczyk R., Luto. M., Wojtas P.: Analiza dokładności oceny niezgodności spawlaniczych wykrywanych w badaniach ultradźwiękowych, Biuletyn Instytutu Spawalnictwa w Gliwicach, $\mathrm{nr} 3 / 2010$, s. 35-40

[7] Krawczyk R., Wosik - Poch K.: Ocena czułości wybranych technik badań magnetyczno-proszkowych, Materiały $39 \mathrm{Kra}-$ jowej Konferencji Badań Nieniszczących, Szczyrk, 25-28 X 2010, s. 39, Warszawa 2010. 